\title{
ANALISIS KINERJA KEUANGAN PT. BANK PERKREDITAN RAKYAT PAGARUYUNG CABANG PADANG PANJANG DENGAN MENGGUNAKAN RASIO RASIO KEUANGAN
}

\author{
Siti Zahara, Jhon Fernos \\ Akademi Keuangan Perbankan "Pembangunan" Padang \\ Jhonfernos@akbpstie.ac.id
}

\begin{abstract}
Liquidity Level of PT. BPR Pagaruyung in 2011 to 2014 looks very efficient or very good. Based on the assessment of the current ratio and cash ratio, the level of liquidity of PT. BPR Pagaruyung shows that the company's liquidity is above the industry average ratio. In terms of the current ratio shows that the company has been able to manage its smooth debt so that the company has a ratio that is above the industry average ratio of 200\%. If seen from the cash ratio, it shows that in 2011 the company was less effective with its financial performance so that the company's cash ratio for the year was less than the industry average ratio. While in 2012 until 2014, the company has improved its financial performance, so the company has a ratio above the average company ratio of $30 \%$. The solvency level of the company from 2011 to 2014 looks very good, because it is above the industry average. Even though there is a decrease and increase every year, both in terms of the debt ratio and the debt equity ratio. This shows that assets owned by the company are very dependent on the debt that is in the company. From the level of company profitability ratios from 2011 to 2014 as a whole also shows a ratio that fluctuates or is erratic from year to year. This increase in increase or decrease is due to the decrease in the amount of net income and the increase in the number of assets. But when viewed from the level of the overall profitability ratio is classified as good, because of the decline in profitability ratio has been above the industry average ratio. If you see the overall results that have been studied based on liquidity ratios, solvency and profitability ratios the company tends to fluctuate and instability over the performance of the company. Nevertheless, PT BPR Pagaruyung falls into the good category and has met industry average standards set by Bank Indonesia.
\end{abstract}

Keywords: Banks, People's Credit, Financial Performance Financial Ratios

\section{PENDAHULUAN}

Perkembangan dunia Perbankan di Indonesia saat ini semakin kompetitif yang mana menuntut setiap Perbankan untuk dapat mengolah dan melaksanakan manajemen Perbankan menjadi lebih profesional. Apalagi Pebankan juga dihadapkan dengan krisis Ekonomi yang melanda pasar Global yang dapat berpengaruh terhadap duni Perbankan di Indonesia. Hal ini juga di ikuti oleh kerentanan likuiditas yang masih terus berlangsung yang akhirnya menimbulkan persepsi Resiko Emerging Market. 
Dilihat dari segi fungsinya, Bank dibagi menjadi dua yaitu yang pertama adalah Bank Umum yaitu bank yang melaksanakan kegiatan usaha secara konvensional atau berdasarkan prinsip syariah yang dalam kegiatannya memberikan jasa dalam lalu lintas pembayaran. Yang kedua adalah Bank Perkreditan Rakyat (BPR) yaitu bank yang melaksanakan kegiatan usaha secara konvensional atau berdasarkan prinsip syariah, tetapi tidak memberikan jasa dalam lalu lintas pembayaran. BPR merupakan lembaga perbankan resmi yang diatur berdasarkan Undang-Undang No. 7 tahun 1992 tentang Perbankan dan sebagaimana telah diubah dengan Undang-Undang No. 10 tahun 1998.

Kinerja keuangan Bank dapat diukur dengan rasio kecukupan modal, Likuiditas, dan rentabilitas. Selain itu besarnya kredit bermasalah yang dimiliki oleh Bank juga dapat dijadikan sebagai tolak ukur yang digunakan dalam pengukuran kinerja Bank. kinerja keuangan perusahaan dapat dinilai dari laporan keuangan Bank. Laporan keuangan merupakan hasil akhir dari proses akuntansi yang mengambarkan kondisi keuangan perusahaan pada suatu periode tertentu yang berisikan informasi yang berguna bagi pihak-pihak yang berkepentingan terhadap laporan keuangan (Riyanto:2003). Laporan keuangan tersebut berupa laporan Neraca, laporan Rugi / Laba dan perubahan modal perusahaan dalam periode tertentu.

Laporan keuangan pada perbankan dapat menunjukan kinerja yang telah dicapai pada suatu waktu serta untuk mengetahui kemampuan perusahaan dalam mengatasi masalah-masalah keuangan perusahaan serta mengambil keputusan yang cepat dan tepat. Melalui analisis rasio laporan keuangan, manajemen dapat mengetahui posisi keuangan, kinerja keuangan dan kekuatan keuangan (financial strength) yang dimiliki perusahaan. Selain berguna bagi perusahaan dan manajemennya, analisis rasio laporan keuangan juga diperlukan oleh pihak-pihak lain yang berkepentingan seperti kreditor, investor dan pemerintah untuk menilai kondisi keuangan perusahaan dan perkembangan dari perusahaan tersebut.

PT. Bank Perkreditan Rakyat Pagaruyung merupakan salah satu perusahaan perbankan yang dalam pelaksanaanya meliputi penghimpunan dana dari masyarakat dalam bentuk simpanan serta menyalurkan dana dalam bentuk kredit kepada masyarakat sebagai penunjang kegiatan perekonomian masyarakat dan masih banyak kegiatan dalam pemberian jasa - jasa yang lain kepada masyarakat. Kinerja keuangan PT. Bank Perkreditan Rakyat Pagaruyung untuk tahun 2012 dan 2013 dapat diketahui melalui laporan keuangan yang berupa laporan neraca dan laporan rugi / laba tahun 2012 dan 2013. Laporan keuangan tersebut selanjutnya dianalisa dengan menggunakan analisis rasio keuangan yaitu meliputi : rasio likuiditas, rasio aktifitas, rasio solvabilitas dan rasio profitabilitas.

Data mengenai rasio - rasio keuangan PT.BPR Pagaruyung dalam kurun waktu $2011 \mathrm{~s} / \mathrm{d} 2014$, dapat dilihat pada tabel berikut :

Table 1

Rasio keuangan PT.BPR Pagaruyung

Tahun 2011-2014

\begin{tabular}{lrrrr}
\hline \multicolumn{1}{c}{ Rasio } & $\mathbf{2 0 1 1}$ & \multicolumn{1}{c}{$\mathbf{2 0 1 2}$} & \multicolumn{1}{c}{$\mathbf{2 0 1 3}$} & \multicolumn{1}{c}{$\mathbf{2 0 1 4}$} \\
\hline Current Ratio & $220,22 \%$ & $248,79 \%$ & $283,32 \%$ & $340,49 \%$ \\
Cash Ratio & $28,41 \%$ & $58,71 \%$ & $35,49 \%$ & $46,63 \%$ \\
Debt Ratio & $85,06 \%$ & $85,81 \%$ & $84,82 \%$ & $84,5 \%$ \\
Debt Equity Ratio & $569,33 \%$ & $670,75 \%$ & $559 \%$ & $545,1 \%$ \\
Gross profit margin & $16 \%$ & $16,35 \%$ & $26,66 \%$ & $36,32 \%$ \\
Net profit margin & $14 \%$ & $14,3 \%$ & $23,1 \%$ & $31,6 \%$
\end{tabular}




\begin{tabular}{lrrrr} 
Return on investment & $2,55 \%$ & $2,32 \%$ & $2,69 \%$ & $3,94 \%$ \\
Return on equity & $17 \%$ & $18,12 \%$ & $17,71 \%$ & $25,45 \%$ \\
Return on asset & $2,9 \%$ & $2,65 \%$ & $3,11 \%$ & $4,5 \%$ \\
\hline
\end{tabular}

Sumber: Laporan Keuangan PT. BPR Pagaruyung, data diolah

Dari tabel 1.bisa dilihat bahwa pada tahun 2011 sampai dengan 2014 rasio likuiditas perusahaan berupa current ratio memiliki nilai yang meningkat di tiap tahunnya, dimana pada tahun 2011 sebesar 220.22\%,2012 sebesar 248.79\%, 2013 sebesar $283.32 \%$ dan 2014 sebesar $340.49 \%$. sedangkan pada cash ratio perusahaan pada tahun 2011 sebesar $28.41 \%$ dan tahun 2012 sebesar $58.71 \%$ meningkat dari tahun sebelumnya sebesar 30.3\% . berbeda dengan tahun 2013 yang mengalami penurunan dari tahun sebelumnya menjadi $35.49 \%$ dan kembali meningkat pada tahun 2014 yaitu menjadi $46.63 \%$. Hal ini membuktikan bahwa kinerja perusahaan dalam mengelola kewajiban yang segera dapat di bayar atau kewajiban jangka pendek perusahaan sangatlah efektif sehingga kewajiban lancar perusahaan bisa di jamin oleh asset perusahaan serta oleh aktiva yang dimiliki.

Dari segi solvabilitas, perusahaan yaitu berupa debt ratio dan debt equity ratio bisa dikatakan kurang baik dalam mengelola kewajiban jangka panjangnya. Hal ini dibuktikan dengan terjadinya kenaikan dan penurunan pada ratio tersebut. pada debt ratio pada tahun 2011 debt equity perusahaan sebesar $85.06 \%$ dan tahun 2012 sebesar $85.81 \%$ meningkat dari tahun sebelumnya. Sedangkan pada tahun 2013 terjadi penurunan menjadi $84.82 \%$ dan menurun kembali pada tahun 2014 yaitu menjadi $84.5 \%$. Meskipun pada 4 periode tersebut terjadi kenaikan dan penurunan, kinerja perusahaan masih bisa dikatakan baik dalam mengelola modal dan asset yang membiayai kewajiban perusahaan.

Adapun pada segi profitabilitas, PT .BPR Pagaruyung termasuk kedalam kategori baik, karena menurut rasio rata - rata industry perusahaan berada di atas rasio rata - rata perusahaan. Dari segi GPM perusahaan memiliki nilai yang meningkat dari tahun - tahun sebelumnya yaitu pada tahun 2011 sebesar 16\%, 2012 sebesar $16.35 \%$, 2013 sebesar 26.66\% dan 2014 sebesar 36.32\%. Dari segi NPM perusahaan juga memiliki nilai yang juga meningkat dari tahun - tahun sebelumnya, pada tahun 2011 NPM perusahaan sebesar 14\%, 2012 sebesar 14.3\%, 2013 sebesar 23.1\% dan tahun 2014 sebesar 31.6\%. Pada ROI perusahaan juga mengalami kenaikan pada tahun 2011 sampai dengan tahun 2014 yaitu, pada tahun 2011 sebesar $2.55 \%, 2012$ sebesar $2.32 \%$, 2013 sebesar $2.69 \%$ dan tahun 2014 sebesar 3.94\%. pada ROE perusahaan mengalami kenaian dan penurunan yaitu pada tahun 2011 sebesar 17\%, 2012 sebesar 18.12\% meningkat dari tahun sebelumnya, sedangkan pada tahun 2013 terjadi penurunan menjadi $17.71 \%$ dan kembali meningkat pada tahun 2014 menjadi $25.45 \%$. Dan pada ROA perusahaan juga mengalami penurunan dan peningkatan, pada tahun 2011 ROA perusahaan sebesar $2.9 \%$ dan 2012 sebesar $2.65 \%$, menurun dari tahun sebelumnya. Dan pada tahun 2013 kembali meningkat menjadi 3.11\% dan kembali meningkat pada tahun 2014 manjadi 4.5\%. Hal ini membuktikan kinerja keuangan perusahaan dalam menghasilkan laba sangat efektif, sehingga. Perusahaan mampu mempertahankan kelangsungan operasional perusahaan dalam menghadapi persaingan sesama jenis usaha.

Berlatar belakang dari masalah diatas, mendorong saya selaku penulis melakukan penelitian untuk dijadikan bahan penyusunan Tugas Akhir dengan judul : “Analisis Kinerja Keuangan PT. Bank Perkreditan Rakyat Pagaruyung Cabang Padang Panjang Dengan Menggunakan Rasio - Rasio Keuangan 
Berdasarkan latar belakang masalah diatas maka rumusan masalah dalam penelitian ini adalah bagaimana analisis kinerja keuangan pt. Bank perkreditan rakyat pagaruyung cabang padang panjang dengan menggunakan rasio - rasio keuangan

\section{LANDASAN TEORI}

Menurut Undang-Undang Perbankan pasal 1 ayat 2 No.10 Tahun 1998 Tentang Perbankan, bank adalah badan usaha yang menghimpun dana dari masyarakat dalam bentuk simpanan dan menyalurkan dana kepada masyarakat dalam bentuk kredit dan atau bentuk-bentuk lainnya dalam rangka meningkatkan taraf hidup rakyat banyak.

Menurut Undang-Undang Perbankan No.10 Tahun 1998 pasal 1 ayat 4 tentang perbankan bank terdiri atas dua jenis, yaitu:

a. Bank Umum

Pengertian Bank Umum menurut Peraturan Bank Indonesia No. 9/7/PBI/2007 adalah bank yang melaksanakan kegiatan usaha secara konvensional dan atau berdasarkan prinsip syariah yang dalam kegiatannya memberikan jasa dalam lalu lintas pembayaran. Bank umum sering disebut bank komersil (Commercial Bank).

b. Bank Perkreditan Rakyat

Bank Perkreditan Rakyat (BPR) adalah bank yang melaksanakan kegiatan usaha secara konvensional atau berdasarkan prinsip syariah yang dalam kegiatannya tidak memberikan jasa dalam lalu lintas pembayaran.

\section{Pengertian Kinerja Keuangan}

Menurut munawir kinerja keuangan perusahaan merupakan suatu gambaran tentang kondisi keuangan suatu perusahaan yang dianalisis dengan alat-alat analisis keuangan, sehingga dapat diketahui mengenai baik buruknya keadaan keuangan suatu perusahaan yang mencerminkan prestasi yang diperoleh perusahaan dalam operasionalnya pada periode tertentu.

\section{Pengertian Laporan Keuangan}

Menurut Munawir (2004:2) Laporan keuangan pada dasarnya adalah hasil dari proses akuntansi yang digunakan sebagai alat komunikasi antara data keuangan atau aktifitas suatu perusahaan dengan pihak yang berkepentingan dengan data atau aktifitas perusahaan tersebut.

\section{Jenis-Jenis Laporan Keuangan}

1. Neraca

Merupakan laporan keuangan yang menunjukan posisi keuangan bank pada tanggal tertentu. Posisi keuangan yang dimaksud adalah aktiva dan pasiva suatu bank.

2. Laporan Komitmen dan Kontijensi

Merupakan suatu ikatan atau kontrak yang berupa gaji yang tidak dapat dibatalkan secara sepihak (irrevocable) dan harus dilaksanakan sesuai kesepakatan bersama.

3. Laporan Laba Rugi

Merupakan laporan keuangan bank yang menggambarkan hasil usaha bank dalam periode tertentu.

4. Laporan Arus Kas

Merupakan laporan yang menunjukan semua aspek yang berkaitan dengan kegiatan bank, baik yang berpengaruh langsung atau tidak langsung terhadap kas. Laporan arus kas harus disusun berdasarkan konsep kas selama periode laporan.

5. Catatan Atas Laporan Keuangan 
Merupakan laporan yang berisi catatan tersendiri mengenai posisi devisa netto menurut jenis mata uang dan aktivitas lainnya.

6. Laporan Keuangan Gabungan dan Konsolidasi

Laporan Keuangan Gabungan merupakan laporan dari cabang-cabang bank yang bersangkutan, baik yang ada didalam maupun diluar negri. Sedangkan laporan keuangan konsolidasi merupakan laporan bank yang bersangkutan dengan anak perusahaan.

\section{Pengertian Analisis Laporan Keuangan}

Harahap mengemukakan analisa laporan keuangan sebagai berikut : "Analisa laporan keuangan yaitu menguraikan pos-pos laporan keuangan menjadi unit informasi yang lebih kecil dan melihat hubungan yang bersifat signifikan atau yang mempunyai makna antara satu dengan yang lain baik antara data kuntitatif maupun non kuantitatif dengan tujuan untuk mengetahui kondisi keuangan lebih dalam yang sangat penting dalam proses menghasilkan keputusan yang tepat.

\section{Pengertian Rasio Keuangan}

Rasio keuangan merupakan alat analisis keuangan perusahaan untuk menilai kinerja suatu perusahaan berdasarkan perbandingan data keuangan yang terdapat pada pos laporan keuangan (neraca, laporan laba rugi, laporan aliran kas/).

\section{Pengertian Analisa Rasio Keuangan}

Menurut James C Van Horne dikuutip dari Kasmir (2008 : 104) analisa rasio keuangan adalah indeks yang menghubungkan dua angka akuntansi dan diperoleh dengan membagi satu angka dengan angka lainnya.

\section{Jenis- Jenis Rasio Keuangan}

\section{Rasio Likuiditas (liquidity ratios)}

Yaitu rasio yang menunjukan hubungan antara kas perusahaan dan aktiva lancar lainnya dengan hutang lancar. Rasio likuiditas digunakan untuk mengukur kemampuan perusahaan dalam memenuhi kewajiban-kewajiban finansialnya yang harus segera dipenuhi atau kewajiban jangka pendek.

\section{Ratio Aktivitas (Activity Rasio)}

Rasio ini dikenal juga dengan rasio efisiensi, yaitu rasio yang mengukur efisiensi perusahaan dalam menggunakan aset-asetnya. Rasio ini menganalisis hubungan antara laporan laba rugi , khususnya penjualan, diukur dengan istilah perputaran unsur-unsur aktiva yang dihubungkan dengan penjualan.

\section{Rasio Hutang (Leverage Ratio)}

Yaitu rasio yang mengukur seberapa banyak perusahaan menggunakan dana dari hutang (pinjaman). Rasio ini dapat dihitung dari pos-pos yang sifatnya jangka panjang seperti aktiva tetap dan hutang jangka panjang.

\section{Rasio Keuntungan (Profitability Ratios)}

Yaitu rasio yang menunjukan kemampuan perusahaan untuk memperoleh keuntungan dari penggunaan modalnya. Rasio ini terdiri dari dua jenis rasio yang menunjukan laba dalam hubungannya dengan penjualan, rasio yang menunjukan laba dalam hubungannya dengan investasi.

Gambaran rata-rata yang paling tepat untuk memberikan gambaran standar rasio yang baik adalah rasio industry. Dengan adanya standar ini, perusahaan dapat menentukan baik atau tidak nya keuangan perusahaan. Penilaian ini dilakukan dengan membandingkan rasio keuangan yang diperoleh dengan standar rasio yang ada. Kinerja perusahaan dapat dikatakan baik apabila besarnya rasio keuangan perusahaan bernilai sama dengan atau diatas standar rasio keuangan 


\section{METODE PENELITIAN}

Dalam pengumpulan data dan bahan untuk melakukan penelitian ini digunakan metode pengumpulan data sebagai berikut :

1. Metode Pengumpulan Data

a. Penelitian Lapangan (Field Research) yaitu suatu metode penelitian dengan cara mendatangi langsung ke perusahaan yang menjadi objek kajian. Teknik pengumpulan data yang dilakukan yaitu wawancara dan observasi.

b. Studi Pustaka (Library Research) yaitu penelitian yang dilakukan ke perpustakaan beberapa buku-buku ilmiah dan tulisan-tulisan yang berhubungan dengan pembahasan yang dilakukan.

2. Metode Analisa Data

Dalam menganalisa data, penulis menggunakan analisis data kuantitatif sebagai metode penelitian yang menjelaskan secara deskriptif mengenai analisis rasio terhadap laporan keuangan PT. Bank perkreditan rakyat Pagaruyung untuk periode 2012 dan 2013. Metode analisis ditinjau dari dua praktek yang perlu diterapkan, sehingga dapat diketahui sejauh mana pelaksanaannya. Apakah perbedaan yang timbul menyangkut prinsip dasar konsep itu sendiri, pertanyaan itu akan terjawab selanjutnya dari hasil analisa itu digunakan sebagai dasar pengambilan kesimpulan dan saran.

\section{HASIL DAN PEMBAHASAN}

Berdassarkan penilaian kinerja PT.BPR Pagaruyung secara keseluruhan dengan menggunakan rasio likuiditas, solvabilitas, aktifitas, dan profitabilitas, maka dapat disimpulkan bahwa kinerja perusahaan selama lima tahun terakhir yaitu dari tahun 2010 sampai dengan tahun 2014 mengalami ketidakstabilan.Kenaikan maupun penurunan ini terjadi karena perusahaan tidak mampu mempertahankan kestabilan kinerja perusahaan. Hasil akhir dapat dilihat pada tabel di bawah ini :

1. Rasio Likuiditas

Tabel 2

PT. BPR Pagaruyung

Perbandingan Rasio Likuiditas

Tahun $2011-2014$

\begin{tabular}{lccccc}
\hline Rasio & 2011 & 2012 & 2013 & 2014 & Rata industri \\
\hline Current Ratio & $220,22 \%$ & $248,79 \%$ & $283,32 \%$ & $340,49 \%$ & $200 \%$ \\
Cash Ratio & $28,41 \%$ & $58,71 \%$ & $35,49 \%$ & $46,63 \%$ & $30 \%$ \\
\hline
\end{tabular}

Sumber : PT. BPR Pagaruyung, data diolah

Current Ratio PT.BPR Pagaruyung pada tahun 2011 sampai dengan 2014 sangat baik, karena current ratio perusahaan berada di atas rasio rata - rata industry. Hal ini membuktikan bahwa perusahaan sangat konsisten dalam mengelola aktiva lancarnya.

Cash ratio PT. BPR Pagaruyung pada tahun 2011 masih berada di bawah rata - rata rasio indusri. Berbeda dari tahun 2012 sampai dengan tahun 2014 perusahaan sudah bisa menunjukan trend yang baik, Karena Cash ratio perusahaan berada di atas rasio rata - rata industry. Dari tabel tersebut kita bisa lihat bahwa cash ratio perusahaan pada tahun 2011 28,41\% menurun jika dibandingkan dengan tahun 2012 yaitu 58,71\%, penurunan tersebut sebesar $30,3 \%$. Penurunan tersebut terjadi karena pengurangan pada 
kas atau yang setara dengan kas serta ketidak mampuan perusahaan dalam memenuhi kewajiban segeranya.Sedangkan pada tahun 2012 sampai dengan tahun 2014 perusahaan mengalami peningkatan dalam mengelola kewajibannya.Sehingga pada tahun 2012 sampai dengan tahun 2014 perusahaan bisa digolongkan dalam kategori sehat, karena cash rasio perusahaan berada diatas rasio rata - rata industry sebesar $30 \%$.

2. Rasio Solvabilitas

Tabel 3

PT. BPR Pagaruyung

Perbandingan Rasio Solvabilitas

Tahun $2011-2014$

\begin{tabular}{cccccc}
\hline \multicolumn{1}{c}{ Rasio } & 2011 & \multicolumn{1}{c}{2012} & \multicolumn{1}{c}{2013} & 2014 & Rata industry \\
\hline Debt Ratio & $85,06 \%$ & $85,81 \%$ & $84,82 \%$ & $84,5 \%$ & $35 \%$ \\
Debt Equity Ratio & $569,33 \%$ & $670,75 \%$ & $559 \%$ & $545,1 \%$ & $90 \%$ \\
\hline
\end{tabular}

Sumber : PT.BPR Pagaruyung, data diolah

Berdasarkan tabel di atas dapat disimpulkan bahwa : Rasio hutang terhadap aktiva PT.BPR Pagaruyung dari tahun 2011 sampai dengan tahun 2014 terlihat sangat baik, meskipun tiap tahunnya terjadi peningkatan dan penurunan. Meskipun demikian rasio debt equity perusahaan berada di atas rasio rata - rata industry.Hal ini terjadi karena pembiayaan perusahaan untuk memperolehseluruh aktiva yang ada lebih banyak menggunakan pembiayaan dari ekuitas.

Rasio hutang terhadap modal PT.BPR Pagaruyung dari tahun 2011 sampai dengan tahun 2014 mengalami kondisi yang naik turun.Meskipun demikian rasio hutang perusahaan tetap berada di atas rasio rata - rata industry, hal ini menunjukan bahwa perusahaan mampu memenuhi pembiayaan aktiva dengan menggunakan ekuitas yang dimiliki dan hanya menggunakan sebagian pembiayaan yang berasal dari hutang.

3. Rasio Profitabilitas

Tabel 4

PT. BPR Pagaruyung

Perbandingan Rasio profitabilitas

Tahun $2011-2014$

\begin{tabular}{lccllc}
\hline \multicolumn{1}{c}{ Rasio } & 2011 & 2012 & 2013 & 2014 & rata industry \\
\hline Gross profit margin & $16 \%$ & $16,35 \%$ & $26,66 \%$ & $36,32 \%$ & $30 \%$ \\
Net profit margin & $14 \%$ & $14,3 \%$ & $23,1 \%$ & $31,6 \%$ & $10 \%$ \\
Return on investment & $2,55 \%$ & $2,32 \%$ & $2,69 \%$ & $3,94 \%$ & $30 \%$ \\
Return on equity & $17 \%$ & $18,12 \%$ & $17,71 \%$ & $25,45 \%$ & $5 \%$ \\
Return on asset & $2,9 \%$ & $2,65 \%$ & $3,11 \%$ & $4,5 \%$ & $0,5 \%$ \\
\hline
\end{tabular}

Sumber : PT.BPR Pagaruyung, data dioalh

Berdasarkan tabel analisis rasio profitabilitas di atas dapat disimpulkan bahwa rasio laba kotor pada PT.BPR Pagaruyung bisa dikatakan kurang baik, karena rasio laba kotor perusahaan pada tahun 2011 sampai tahun 2013 masih berada di bawah rasio rata - rata industry yaitu sebesar 30\%. Dan hanya tahun 2014 saja yang memiliki rasio di atas rasio rata - rata perusahaan.Meskipun demikian kinerja keuangan PT.BPR Pagaruyung masih bisa dikatakan sudah cukup baik meskipun belum maksimal. 
Margin laba PT.BPR Pagaruyung sudah bisa dikatakan baik, karena kemampuan perusahaan dalam mendapatkan laba sangat baik sehingga rasio margin laba berada di atas rasio rata - rata industry sebesar $10 \%$.

ROI PT.BPR Pagaruyung bisa dikatakan kurang kurang baik, karena pada tahun 2011 sampai dengan tahun 2013 perusahaan memiliki ROI yang berada di bawah rasio rata - rata industry yaitu sebesar $30 \%$. Hal ini menunjukan kinerja keuangan perusahaan kurang efektif dalam menghasilkan laba bersih dari asset atau total aktiva yang dimiliki perusahaan. Tetapi kinerja keuangan perusahaan kembali meningkat pada tahun 2014, dengan menghasilkan laba bersih sebesar 3,94\% dan berada pada rasio rata - rata industry.

ROE yang dimiliki PT.BPR Pagaruyung sangat terlihat baik.Kemampuan perusahaan dalam mengelola modal untuk menghasilkan laba bersih sangat efektif.Hal ini dibuktikan dari ROI yang dihasilkan perusahaan selama 4 periode tersebut berada jauh di atas rasio rata - rata industry, sehingga perusahaan bisa digolongkan dalam kategori baik.

ROA yang dimiliki oleh PT.BPR Pagaruyung juga dalam kondisi yang sangat baik, Karena ROA yang dihasilkan oleh perusahaan berada di atas rasio rata - rata industry. Hal ini juga membuktikan bahwa kinerja keuangan perusahaan sangat efektif dalam menghasilkan laba usaha dari total aktiva yang dimiliki oleh perusahaan.

\section{SIMPULAN}

Berdasarkan analisis laporan keuangan dengan menggunakan rasio likuiditas, solvabilitas dan profitabilitas dalam menilai kinerja keuangan pada PT. BPR Pagaruyung dari tahun 2011 sampai dengan tahun 2014, dapat ditarik kesimpuln sebagai berikut :

1. Tingkat Likuiditas PT. BPR Pagaruyung pada tahun 2011 sampai dengan 2014 terlihat sangat efisien atau sangat baik. Berdasarkan penilaian current ratio dan cash ratio, tingkat likuiditas PT. BPR Pagaruyung menunjukan likuiditas perusahaan sudah berada di atas raio rata - rata industry. Dari segi current ratio menunjukan bahwa perusahaan sudah mampu untuk mengelola hutang lancarnya sehingga perusahaan memiliki rasio yang berada di atas rasio rata - rata industry yaitu sebesar 200\%. Jika dilihat dari cash ratio menunjukan pada tahun 2011 perusahaan kurang efektif dengan kinerja keuangannya sehingga cash ratio perusahaan pada tahun tersebut kurang dari rasio rata - rata industry. Sedangakan pada tahun 2012 sampai dengan tahun 2014 menunjukan perusahaan sudah meningkatkan kinerja keungannya, sehingga perusahaan memiliki rasio di atas rasio rata - rata perusahaan yaitu sebesar $30 \%$.

2. Tingkat solvabilitas perusahaan pada tahun 2011 sampai dengan tahun 2014 terlihat sangat baik, karena berada di atas rata - rata industry. Walaupun disana terlihat bahwa setiap tahun terjadi penurunan dan peningkatan, baik dari segi debt ratio maupun debt equity ratio. Hal ini menunjukan bahwa aktiva yang dimiliki perusahaan sangat bergantung pada hutang yang ada pada perusahaan.

3. Dari tingkat rasio profitabilitas perusahaan dari tahun 2011 sampai dengan tahun 2014 secara keseluruhan juga menunjukan rasio yang berfluktuasi tau tidak menentu dari tahun ketahun. Kenaikan kenaikan atau penurunan ini terjadi karena menurunnya jumlah laba bersih dn meningkatnya jumlh aktiva. Tetapi kalau dilihat dari tingkat rasio profitabilitas secara keseluruhan sudah tergolong baik, karena tingkta rasio profitabilitas penurunan sudah berada di atas rasio rata - rata industry. 
4. Jika dilihat hasil keseluruhan yang telah diteliti berdasarkan rasio likuiditas, solvabilitas dan rasio profitabilitas perusahaan cenderung berfluktuasi dan ketidak stabilan atas kinerja perusahaan. Meskipun demikian PT BPR Pagaruyung termasuk kedalam kategori baik dan telah memenuhi standar rata - rata industry yang ditetapkan oleh Bank Indonesia.

\section{DAFTAR PUSTAKA}

Arifin, I. Z., \& Marlius, D. (2017). Analisis Kinerja Keuangan PT. Pegadaian Cabang Ulak Karang. https://doi.org/10.31227/osf.io/n2peu

Bank Indonesia, 1992, UU No. 7 tahun 1992, tentang Perbankan, Jakarta. 1998, UU No. 10 tahun 1998, tentang perubahan terhadap UU No. 7 tahun 1992, Jakarta.

Dendawijaya, Lukman, 2003, “Manajemen Perbankan”, Ghalia Indonesia, Jakarta.

Jusuf, Haryono, AL. “Dasar - Dasar Akuntansi”. Yogyakarta: STIE YKPN.

Handayani, M., \& Marlius, D. (2017). Analisis Tingkat Kesehatan PT. BPR Batang Kapas. https://doi.org/10.31227/osf.io/bq48z

Harnanto, 1991, “Anlisis Laporan Keuangan", Edisi 4, UPP AMP YKPN, Yogyakarta.

IAI, 1999, “Standar Akuntansi Keuangan", Salemba Empat, Jakarta.

Ikatan Akuntan Indonesia, Pernyataan Standar Akuntansi Keuangan No. 1, Revisi 2009, Dewan Standar Akuntansi Keuangan Ikatan Akuntan Indonesia, Jakarta.

Iswari, M., \& Fernos, J. (2019). Analisis Tingkat Kesehatan Bank Pada PT. Bank Pembangunan Daerah Sumatera Barat. https://doi.org/10.31227/osf.io/ja7ty

Kasmir. 2012. Analisis Laporan Keuangan. Edisi Ke 1-5. Jakarta: Rajawali Pers.

Munawir, 2000. Analisa Laporan Keuangan. Yogyakarta : Liberty

Munawir, S. 2004. Analisa Laporan Keuangan. Yogyakarta: Liberty.

Munawir, 2007. Analisa Laporan Keuangan. Yogyakarta

Putri, Y. A., \& Marlius, D. (2018). Analisis Tingkat Kesehatan Bank Pada PT. Bank Perkreditan Rakyat (BPR) Jorong Kampuang Tangah Pariaman Cabang Padang. https://doi.org/10.31227/osf.io/r98pv 
Rahmayeli, D. S., \& Marlius, D. (2017). Analisis Kinerja Keuangan Pada PT. Bank Perkreditan Rakyat (BPR) Batang Kapas Pesisir Selatan. https://doi.org/10.31227/osf.io/sz5db

Sartono,Agus. 2005. Manajemen Keuangan. Yogyakarta: BPFE

Suherti, E., \& Fernos, J. (2019). Analisa Rasio Terhadap Laporan Keuangan Pada PT. Bank Pembangunan Daerah Sumatera Barat. https://doi.org/10.31227/osf.io/9zte8

Sugiono, Arief dan Edy Untung. 2008. Panduan Praktis Dasar Analisa Laporan Keuangan. Jakarta: PT. Grasindo

Weygandt, 2008. Analisa Laporan Keuangan. Jilid 2, Jakarta. 